\title{
音声の可視的描写とその補緅学的応用
}

\begin{abstract}
関 根弘* 阿部 勤
の他の装置と较べな゙ら，可視様式㚆換の原理およびそ の装置の稞造・記録などを简策に説明し，さらにこのよ

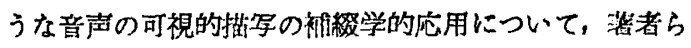
の契臥例をあげて述へてみよう。
\end{abstract}

口唯を印心とする杪音器官の疾病または異常によつて 惹起された発音障客に対して，発音機能の回復をはかる こと，あるいは，生来芳しから好発普を改善していくこ

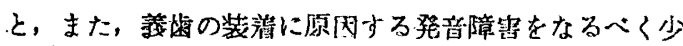

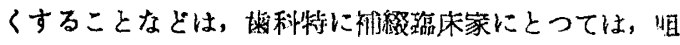
踭機能の回復，外観の修復およひ改善などとともに，極 めて重要な課題である。

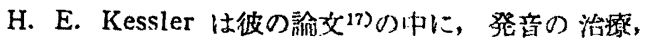
改善の面で、崡科医師は主役を㴼ずるものであると，そ の使命と责任を強調している、声はマイクロフォンを通 して闑かれる機会が多くなり，しかも增幅器を適当に諯 節することにより，弱い単調な，力のない声でも，強 く，多彩な，力に溢れた声に，自伯に变えることができ るが，一方このために，嚾かに耳影りのるような発普

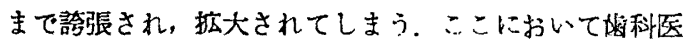

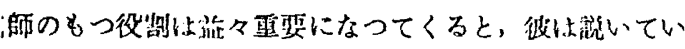
る.

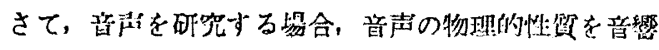
物理学的に愉捨することが第一步であり,さらに発音と

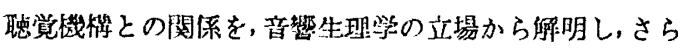
に進んで生理的または物理的現象と人閒の感覚との閣国 を心理学的にも考察与る必要がある。をこでわれわれは 先ず音声の物理的性質から怜討していかねばならない，

音声の物理的性貿を研究主る場合の最も重要な課題 愔声を如何なる形でとらえるか、ということである。 音声をとらえるには，やはり，本来の聴覚によるのが最 も正確で忠実な方法であるとはいえるのであるが，客微 的な観察を行うには，音声を記録し，分析することので きる方法を採らねばならない，それには音を可視棁式に 卒換すること，つまり目で見える形に㚆えることが最適 である。そしてこの目的のために現在用いられている可 視装置には種々のものがある。

そこで現在使用されている可視装置の中で，最も進歩 したものといえる Sound spectrograph を中心にそ

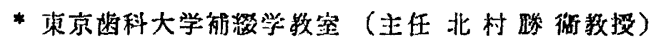

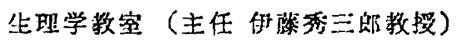

\section{II 豆声可視裝置について}

発声器官から生み出された音声は，空気の踈泌波であ る音诐の形をとる。この等波を可視的な设形に亲換する のがこの装置である，先ず音波はマイクロフォンと增幅

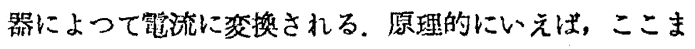
ではどの装置でも共逝でありこの音声笔流つまり振趿

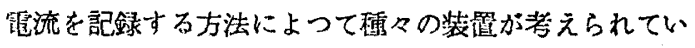
る.

例えば，電磁オシログラフを用いる喣合は，この光声 雪流を銅線に通し，二れを磁石の磁場の中に尊き，電流 の強弱に比例して振動するその銅楾にとりつけられた小 さな鏡に，レンズによつて集められた線をあてること によつて，鏡の反射て鈳線の振趿を拡大した光の振勒に

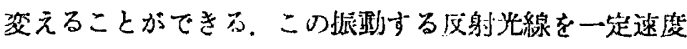

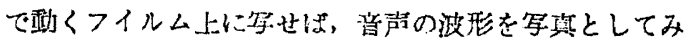
ることができる。

あるいは，音侕電流を磁合録音器の録音へッドの潜線 に流すことによつて，録音テーフ上の磁性粉末を，電流 の強弱に応じて磁化することができる。このテーブを微 小鉄粉またはマグネタイトのコロイト溶液に浸すと，編 模梀 ${ }^{12}$ が現われ，音波の可視的描军が可能である。

また，音声電流をブラウン管オシログラフに运き，X 線用フイルムで写真を掫ることによつても，音波汢可視 栐式に変えることができる。

このようにして得られた振動波形は，振勳振幅の時間 的変化を現わすもので，振動現像の最も忠実な表現方法 である.こうした波形を直接観察することにより，ある 程度の音声の性筫を知ることができ，更に進んで，フー リエの分析法を行えば，その波形を檄成している成分を 詳細に観祭することができる。

\section{Sound spectrograph(Sonagraph)}

前述のような波形による周波数成分の钼察は, 主とし 


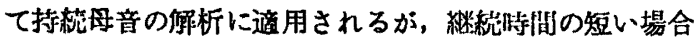
は難しくなり，特に子音のような継綄恃間の短いものの 分析には利用し蘸い，音声の聴敩的特性を把握するに

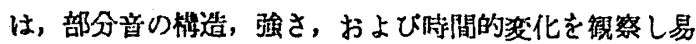
い四形に現わす必要がありこの目的のためには，オシ ロクラフによる波形あるいはフーリエ分析図では不充分 である、このような要求に沿つて考案されたのがSound spectrograph（阔品名 Sonagraph）である。

\section{1. 周波数分析装置の原理}

ソナククランは音を分析して周波数成分の性筫を可視的 な四形に記録する装置である。この原理を理作するに当

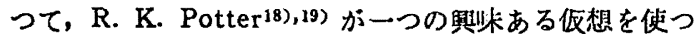
て，理解し易い説明を与えているので，先ずここで，彼 の諭文の一部を平易に解説してみよう。

音波は耳の Corti 氏器官で捕えられ，聴神経を経て大

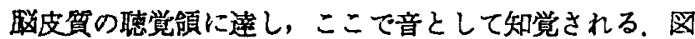
1のAは耳，畋およびこの両者を結ふ心聴种経束の模型図

图 1
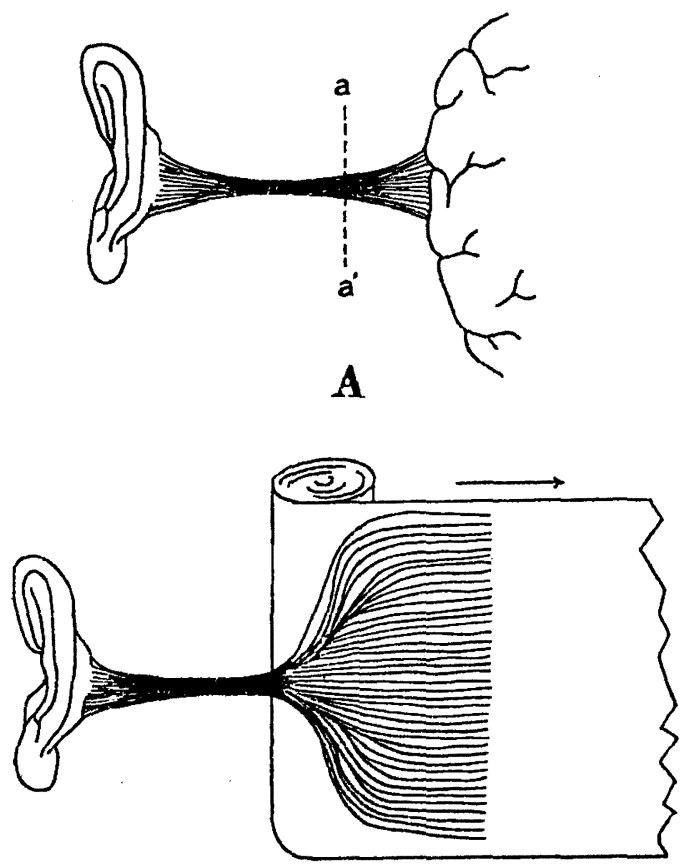

B

である、今，ある方法によつて、 $a-a^{\prime}$ の部分で㥁种経 束を，耳の㥙覚を妨げることなく切断することができる ものと仮定する．次に，耳から来る個々の神経線維を全 部分跳し，各切断端を螖牛内の基底膜に沿つた個々の末
端器に非絡する㮌序に並へ，図1 B のように，各切断端 に記録をとりつけ，一定の速さで動く記録紙に橫に配列 する. 神経末端の数は恐らく 2 万個を数えるものと考え られる。こうした仮定的な配列によつて，すへての神経 線維から伝引る熘号を描記して行けば，音に対応した模 㥞を記録することができる。この場合，各末端器はそれ それ，選択的に沈つた周波数成分のみに感し，各神経線 維はその興峦を伝達する．そして記録針は伝つてくる決 められた周波数成分の強さの時間的瓷化を，記録紙の上 に溯淡の模様として描記していくのである．今ある一つ の神経線維をとりあげてみると，耳に入る音波にその神 経線維に決められた周波数成分が含まれていない場合 は，記録紙上には何も模㴍が現われない，逆に非常にそ の成分が強い場合には，極めて瀶い模様として現われる ことになる。

以上は Potter の仮想的な説明であるが，これを実際 の周波数分析装䁂に睔じて考えると次のようになる。

四2のマイクロフォンMでとらえられた音波は褆雑な音

图 2

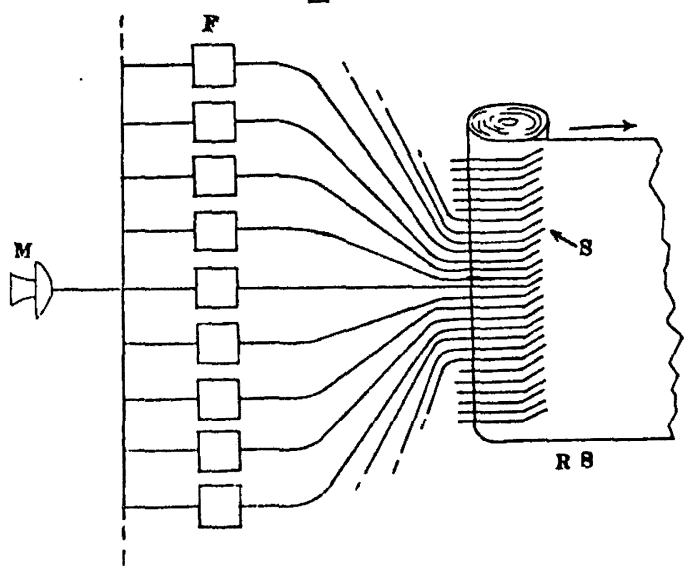

图 3

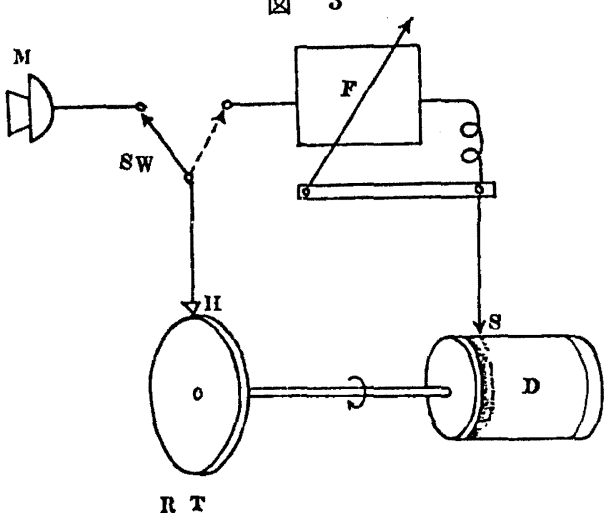


声华流に変えられて、これは次の一速のフイルタ一群 $\mathrm{F}$ に流される。このフィルターは, 電気沃波器で, それぞ れ一定の周波数帯域の成分のみを通し，之の他の周波数 成分は通過させない性啠のものである。

それでこのフイルター群を通過した管流は，それそれ

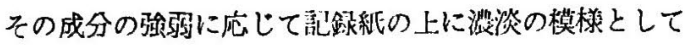
印記される。

\section{2. ソナグラフの機柱}

前項で速一たような周波数分析装筧が，䒠際に使われ ている形をとつたものがソナゲラフで，図3にその機蓝 を示す、恳の下で示した一速のフイルタ一群と，Sで

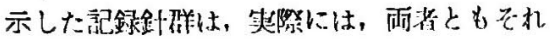
ぞれただ一個のフイルターと記録針が使わ れ，同し墈きをしている，才なわち，図3の

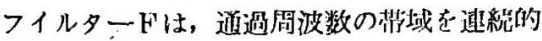
に変えることができ，図 2 の数多くのフイル ター群と同じ效果を発揮する。 しかもその可

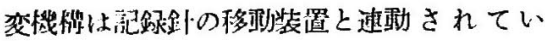
る. 先ず音声をマイクロフォンMを通して䨖 流に変元，これを録望・再生へットHによつ て Endless の録音盤 RT に録音する. 次に 切換スキッチ SW を右に切換えて，録音然加 ら逆にHを通して電流を再生させる。この電 流を図の右の回路に流すことにより，録音盤 と同軸で同速度に回忶する円筒Dに挍きつけ た記録紙（電流が流れた部分が毗化する）に 電流の強弱を黒白の溜淡の模棣に描 記させ る。一回転の再生で，㐫る周波数笁国だけをフイルター でとり出し，同時に円筒が一回板する問にこれを記録す る. 回枟每にフイルターの選択居波数带域と記録針とを 同時に連緮的にずらして行き，何回も数多く回転を繰返 す開に全部の周波数带域（ $0 \rightarrow 8000 \mathrm{c} / \mathrm{s})$ を順次記睩す

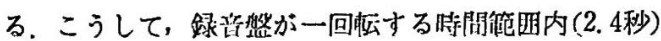
に録音された音声は，記録紙の上に，維斩に周波数を，

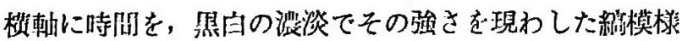
として描写される。

\section{3. ソナグラムについて}

ソナグラフによる音の分析図つまり前述した繶模楼図 をソナグラムという。因4 A は日本語の母音「ア， 1，ウ，エ，才」のソナグラムである．縰軸に，下方 0 $\mathrm{c} / \mathrm{s}$ 加ら上方 $8000 \mathrm{c} / \mathrm{s}$ に至る周波数を, 槛軸に左加ら右 に時間の経過を，黑白の榄淡は成分の強さを示してい

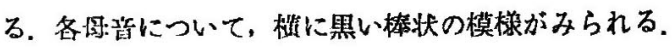
これはフォルマント (英 Characteristic freqency region，独 Formant）とよばれるもので，その青音の其 振周波数带域つまり共嗅成分を示し，その母音を特徽つ けるものである。したがつて，フォルマントの位置は各 母音についてほほ一定している.このフォルマントには 周波数の低い方加第 1 フォルマント $\left(F_{1}\right)$ ，第2 7 ォ ルマント $\left(\mathrm{F}_{2}\right)$ 第 3 と媔次名称が与えられ，こ れらのフォルマントの位置と阾さを見ればをの度音が何 であるかを知ることができる。

图 4
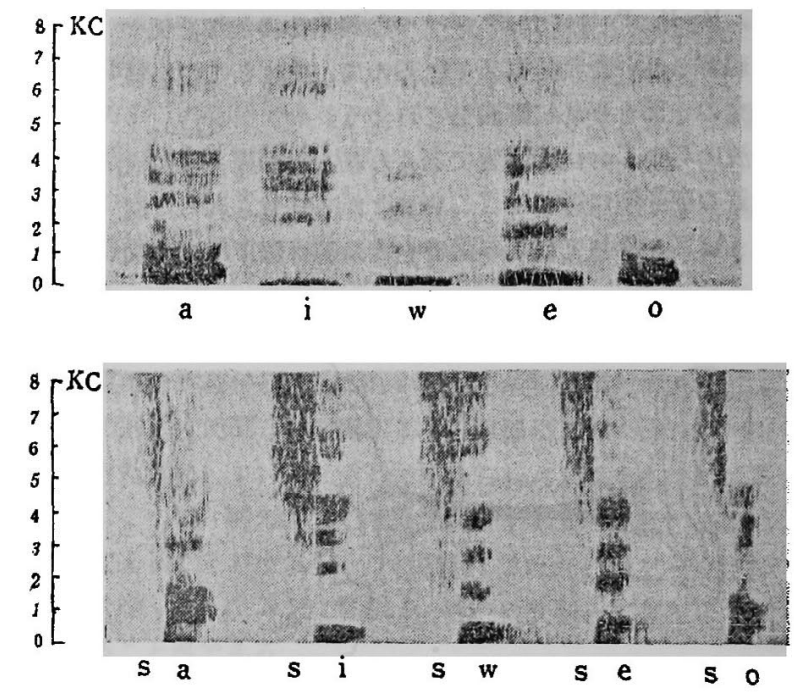

図 4 Bは日本語のサ行「サ，シ，ス，セ，ソ」のソナ グラムである，各音節のはじめに現われている広い周波 数篗围にわたる霜降り状の模様が子音 SまたはSを示

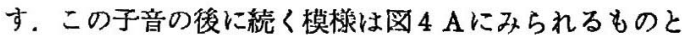
ほ快同じで，それぞれの後綂母音を示している。この図 に現われたものはSの子音のみであるが，子音の程烧に よつて特有の模様を現わす。

ソナグラムにはこの他に，各成分の强さを定量的に䘽 祭するために，黑白の滥淡で現わす代りに，線の展さで 現わす方法があり，セクションとよばれているぶ，この 説明は省略する。

\section{IV 可視的描写による晋声の研究 とその補綴学的応用について}

以上，音声の可視的描写法についで，その原理，装 置，描写記録などの概略を述べたが，音声を研究する場 
合の最も重要な方法であり，從来このような手段によつ て音声の物理的性質についての数多くの研究が行われて きた。㙁科の領城においても，オシロクラフによるもの としては，楠7)，山(本16)，中村11)，菅谷(5).らの研究があ り，更に补嗓学的方面においては，同しくンシログラフ を用いた福本()，出井ららの研究がなされている、ま たソナグラフによるものとしては，弘田2)，伊藤(6ら の研究があり，何れも，歯牙および口㓐の種々の状態と 音声の性筫との関係を㭘討したもので，音声の腹科学上 からの究明に笴与するところが大きい，薯者らも，主と して補槡学的立場から、ソナグラフによる音声の柃討を 試みつつあるが，すでに，義姚に扔ける人工桃の配列と

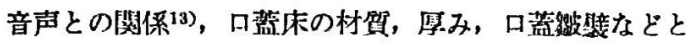
発音との関係 ${ }^{14)}$, あるいは, 義绦設計と発音との関係 ${ }^{3)}$ などにつき，若干の知見を得ている。ここでは，口盐補 辍を行つた息者の発酱についての観祭結果を報告するこ ととした.

\section{V. 、蓋補経についての奏殹例}

\section{1. 手術後の構音障害}

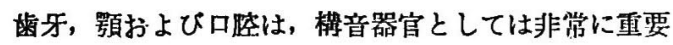
なものであり、これが先天的なまたは後天的な形態の買 常によつて，橔音障害を起すことは周知のとおりであ る. そしてこのような杪音障害については，從来多くの 音声学的研究が行われてきた. 森川(8), 弘田22, 管谷 ${ }^{15}$ ), 永井10)，宮崎》らの報告がそれである。

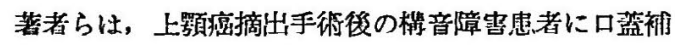
积を行い, 補級処置前後の発音の卒化を, ソナグラフに よつて摡祭した。このような症例にあつては, 補綴処置 によつて, 聴覚的にも著しい橔音機能の回復を示すが, 従来, これに対する音声学的很然を行つた報告は少な い.

图 5

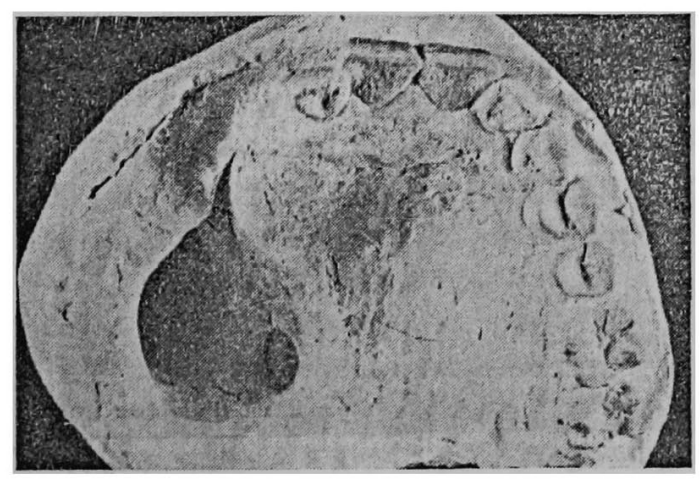

\section{2. 被験者亡補綴処置}

被験者は29才の女子. 生育地東京. 上顎癌摘出手術に

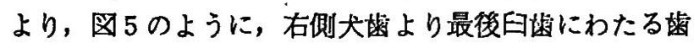
牙欠如および㨙卵大の实質欠椇がある。空洞は，直径約

图 6

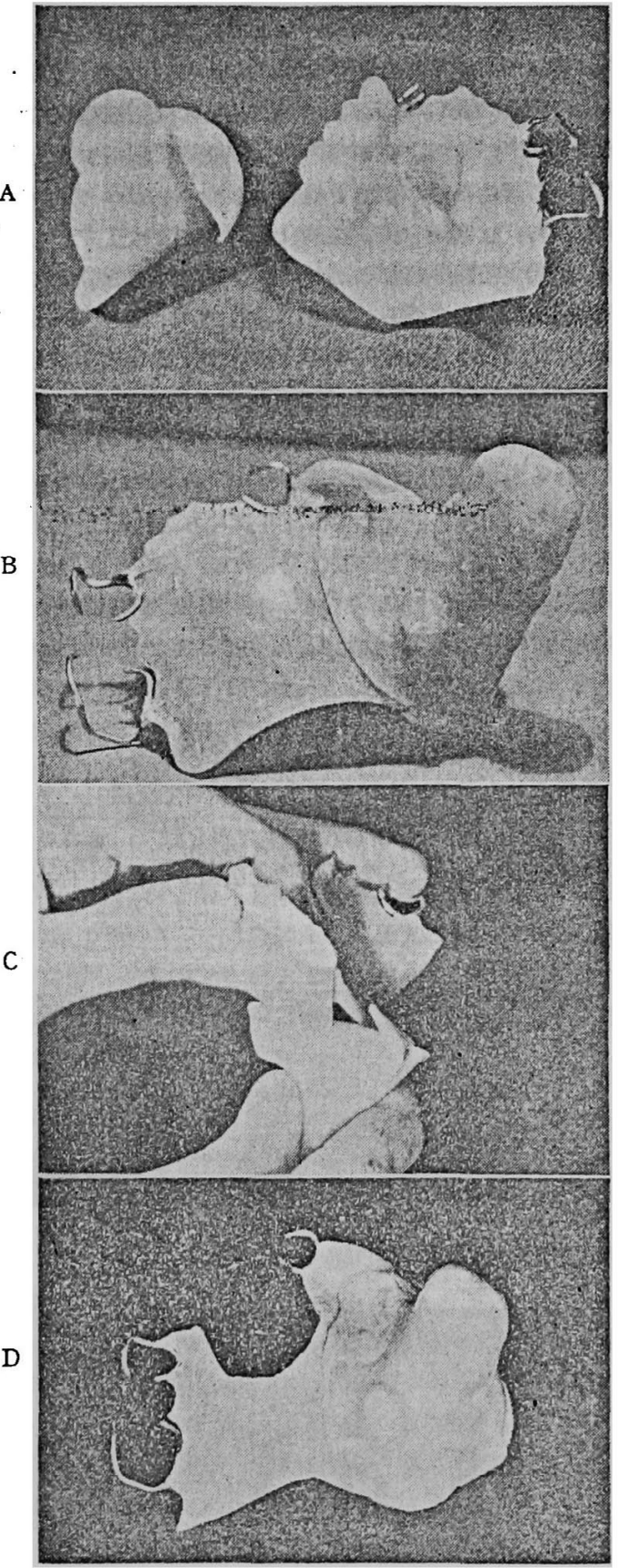


10mmの孔を介して舅腔に通じている。 昭和31年11月，手術を受け, 同32年 3 月，第 1 回目の 補綴物（因6 AおよびB）を装着した，ての後，同年 9 月, 手術創の变化に応して, 第 2 回目の補緅物（図 $6 \mathrm{C}$ およびD）を装着した，その後現在まで約 1 年を経てい るが，経過は極めて艮好である。

補綴物は, Acrylic resin による有床局部義四と,こ れに対して可撤性の栓塞子Obtulator の二つからなる. 患者に軽底の閏口障害があつたことと，欠椇部空洞に僅 かなアンダーカットがありこれを維持に利用するため の二つの理由から，義粀と栓然子を two piecesにした。

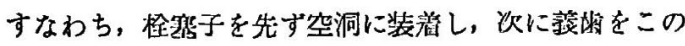
上に装着する順序になるが，栓塞于を装㦈する場合，て れをやや回韭しながら，拱抗の最も少い摴入方向を指の 感じで見出しながら捙入すると容易に装着できる。この

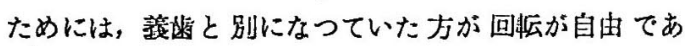
る、しかも，義菌をこの上に装着した場合は，回忶が妨 げられるので, 篮かなアンダーカットのために維持が良 好である，可筑装置としては，写真にみられるようなレ ジンの精密なフックを作り, 発音洔に, 栓塞子と媇堁と の間に起る可能性のある“ビリッキ音”つまり両者の能 れ合う振勤音の発生を防止した。

\section{3. 音声学的实験方法}

手術後, 補槢処置を行う以前の発音状態 (以下 $($-)の 記号でこれを示す)をソナクラブよつて記録し，さら

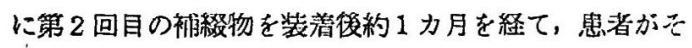

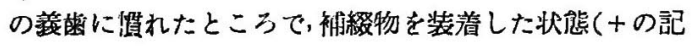

号で示す)で再びソナグラフによる記録を行つた。

\section{4. 実験結果}

1）册音について

母音イエアォウについて（ー）と(十)とを記録したも のが図 7 Aである.

(一) と（十）とを比較すると，全般的に（一) の方が フォルマントの形成が弱く，と〈に：イにおいて第2〉

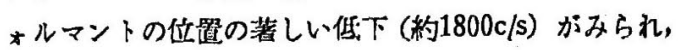
エおよびウもその傎がみられる。「，オにおいては

(一)と（+）との差はあまり落明でない.

このような母音について，その第 1 ，第 2 フォルマン 卜の間波数带域を䚯测して、グラフを描いたものが図 8 である。これ恃正常者の㫮声と比較するために，上居・ 佐滕》の原図に対して本症例の测定值によるフォルマン トの位置を記入したものである.これをみると、ア， オが補緅処置前後にほとんど大きな媇覢を示さないのに 較べて，イ，エおよびウには裂勤がみられ，とくにイ が（一）のときは，ウの領域まで低下した位置にある。 このことは，患者にイを発暑させても，㭱とんどウに近 いように閌こえるという，蚛賞的印象とよく一致してい る.

\section{2. 子音について}

（一）のとき，とくに恥覚的に蘶しい障害の認められ た力行，行，タ行についてソナグムを記録した.

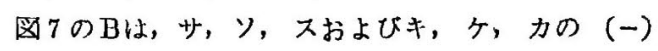
（+）此較ソナクラムである、いずれも（一）では先行
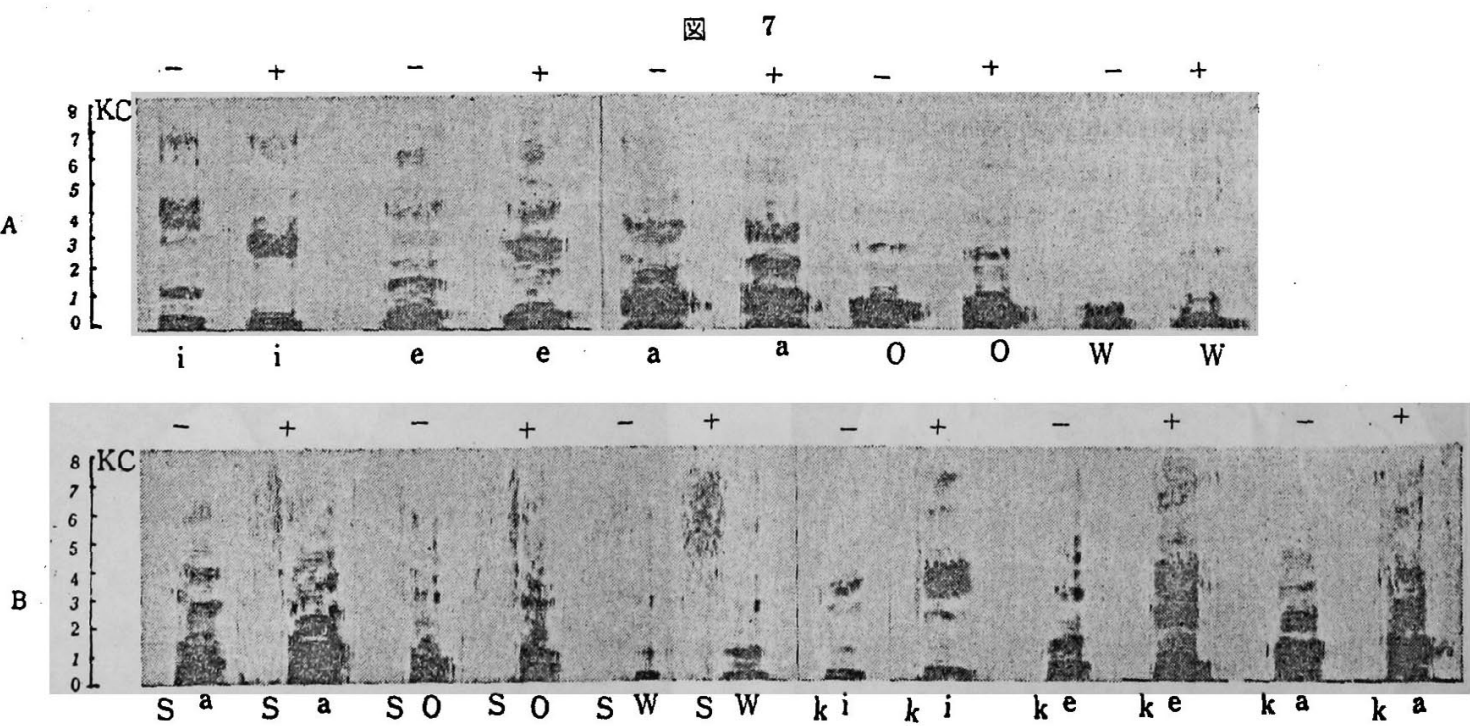
図 8

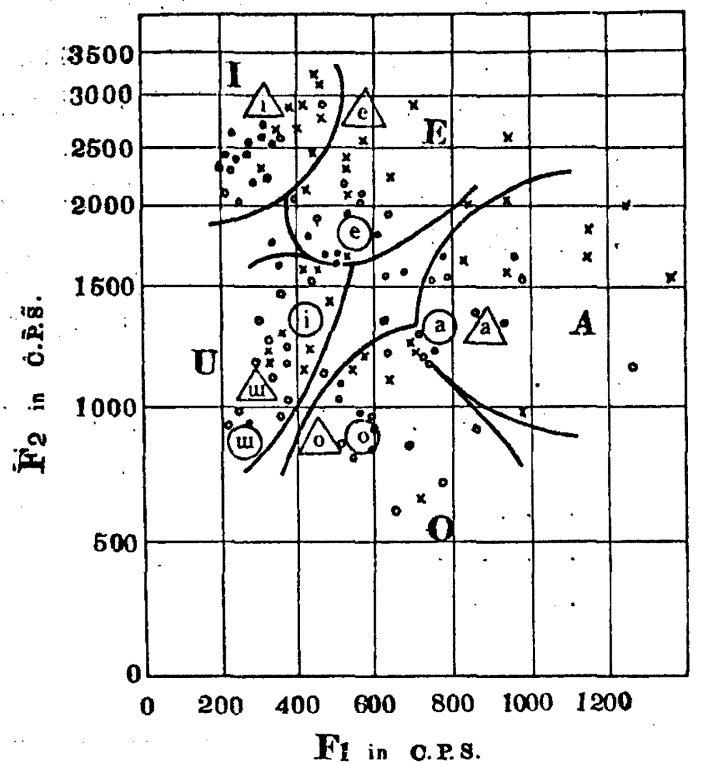

$\mathrm{F}_{1} \mathrm{~F}_{2}$ Diagram

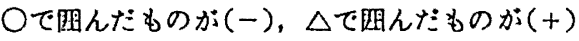

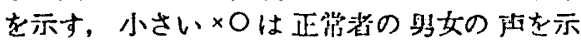
吉。

子音 $\mathrm{s}, \mathrm{k}$ 弱く, これに刘して，（+）では子音成分 の回復が藷しく認められる。これ汒，発音洔の呼気が架

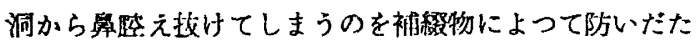
めに，醇势望または破翌音としての子音の発生が完全に なつたためであると考えられる。したがつて（十）で は先行子音の継繶時閒む延長し，母音部人の移行部も明 膫度を增している，後続母音にみられる（一）と（+） との変化は，前述した母音単独の場合とほとんど同じで ある。

\section{5. 考察および結諞}

1）この症例にみられる橏音障害は，母音ではイ，エ に最も大きく現われ，ウがこれに次ぎ，ア，才には比較 '的少い.このようにイ，エおよびウに特にいちじるしい 障客がみられることは，イ，エ，ウは口真に対する舌の

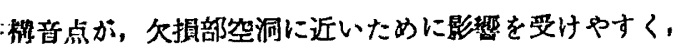
かつ棈残時の口腔容程がア，オの場合より小さいため

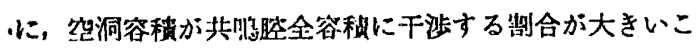
とによるものと考えられる.

2）本症例の㭗音障害は，衫程処置前においては，ほ ととん゙言語として弁別できい犁度にいちじるしいもの であるが，補般処置によつて，ある程度の悬音は残ると
しても，烦る影著な回復を示す。このことは，一度も稗 㫮迅趿を習得したことのない先天的口藍破裂にみられる 糡音症とは，本貿的に翼なる点である。すすなわち，この 患者は手衍前においては, 正常な粸音器官を有し, 正し

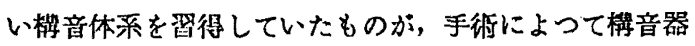
官の主として形態的変化を起したために障宫をきたした ものである.したがつて，このような後天的鼻音症は， 補緅処置すなわち久損部位の形態的修復によって, 構音 の回復仙比較的容易であることを示すものである.

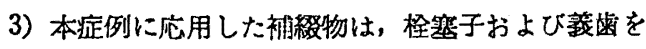
何れも Acrylic resin で作り，しかも栓塞子を中空に し，かつ義速と可撤性の連絡を行つたが，二れらについ ては，更に音響学的あるいは音声医学的立場から，その 設計，材質，椪造，重量，密度，硬度，固有振勒数その 他の要素から梌討を必要とし，一方，口目内での咀摆機 能, 篦害性, 耐久性, 加工性, 强度などの補経学的条件 と相容れられるものであることを贸する。このようなこ とが今後に解決さるべき閂題であると考える.

\section{VI 結 び}

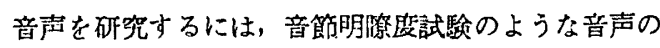
本来の知覚である聴覚による方法もあるが，これる客観 的に詳細に锶察するには、これを可視的に描写する方法 が最適で，かつ応用面でも倀れていると考えられる。こ のような音声の可視的描写法とは如何なるものであるか を簡敞に述へ，さらにこの方法の補経学的な応用につい て，舶者らの実験例をあげて説明した。こうした研究が さらに進歩すれば, 発声, 㮖音, 恥覚などに関する音声 の生理学的あるいは心理学的な研究とあいまつて, 義橉 の材料, 設計あるいは人工畔配列などの発音機能上から の基滥を与える面に広く応用され得るようになると考え る.

本研究に当つて，御指導と御校閲を赐つた伊藤秀三郎 教授ならびに北村腾衙教授に深謝する。

\section{主要考文献}

1）土居：日本音声の実験的研究, 東京, 1955, 岩波 眘店, P. 9.

2）弘田: ソナクラフレよる発音の研究, 崡科学報, $56-5: 16 \sim 25,56-6: 18 \sim 25,56-7: 25 \sim 27,56$ $-8: 12 \sim 17,56-9: 23 \sim 28,1956$.

3）弘田・關根・荒井・吉沢・兴井：涹㙁設計に対す る觜声学的一考祭, 挴科学報, $58-8,1958$.

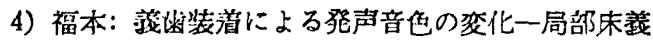


歯に於ける母音及び子音の变化，52-1：12１6，1952.

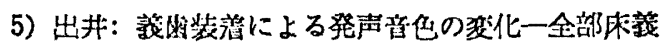

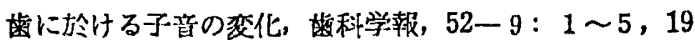
52 .

6）伊藤·弘田·吉次：サ行模音障皆のVisible-speech について, 音声学会会報, 94: 5 7， 1957.

7）楠：畨东欠損による発音障碍のオシログラフ的並 びに音声学的研究, 大日本骖科医学会会誌, 402,19 42 .

8）森川：口藍破裂綘合後の発声並びに燕下障碍に吋 する整形手術的覆正法, 大日本耳鼻咽唉科会会報, 45卷 の上, 1929.

9）宮崎・今井・墺野：上顎喠瘘摘出後の模音障害に

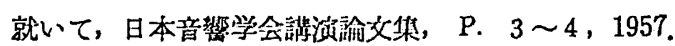

10）永井・宮崎・北村・福島・真田：口登破裂患者の 音声について，日本音響学会にて口演，10月，1955。䍀 演抄録P.71 72.

11）中村：㘿列恔合と発声との関係についての研究， 口腔街生学会雑誌, 4-2: 95 104, 1955.

12）大泉：録音テープの粉末模模による音声奄流の分
析，東北大電通談話会，20-4, 1954.

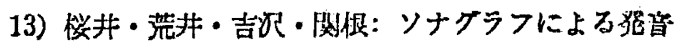

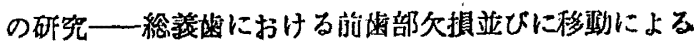
発音の㚆化, 特に行について, 憎科学報, 58-6: 附 1958 .

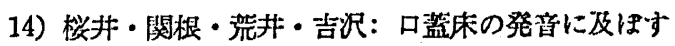
影篦, 墔科学報, 58-8, 1958 .

15）菅谷：口搵破裂舁者の乎術前後における発声音色 に関する研究，橧科学報，52-6:15〜20, 52ー7:14 $\sim 20,1952$.

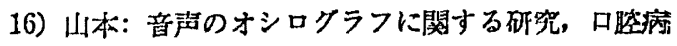
学会雑誌, $17 \sim 6: 453,1942$.

17) H. E. Kessler: Phonetics in denture construction, J. A. D. A., 54: 347 351, 1957.

18) R. K. Potter: Objectives of Sound Portrayal, New Jersy, 1948, Bell Telephone Lab.

19) R. K. Potter - G. A. Koph - H. C. Green: Visible Speech, New York, 1947, D. Van. Nostrand Co.. 